Article

\title{
Consumer Intention toward Bringing Your Own Shopping Bags in Taiwan: An Application of Ethics Perspective and Theory of Planned Behavior
}

\author{
Sheng-Hsiung Chang * (1) and Ching-Hsien Chou \\ Department of International Business, Tamkang University, New Taipei City 251, Taiwan; csherryc@hotmail.com \\ * Correspondence: shchang@mail.tku.edu.tw; Tel.: +886-226-215-656 \\ Received: 29 March 2018; Accepted: 25 May 2018; Published: 31 May 2018 \\ check for \\ updates
}

\begin{abstract}
Following Chan and coworkers' (2008) research, the current study integrated Hunt and Vitell's (1986) ethics perspective and Theory of Planned Behavior (TPB) to present a model that explains consumers' intention to "Bring Your Own Shopping Bags" (BYOB) with grocery shopping. The proposed model is empirically validated in Taiwan. Based on a survey of 601 respondents, the findings suggest that consumers' deontological evaluation is positively related to their attitude, subjective norm, and perceived behavioral control, while teleological evaluation is positively related to perceived behavioral control only. In addition, the results also indicate that consumers' attitude and perceived behavioral control has a positive relationship with BYOB intention, while subjective norm does not have a signification relationship with BYOB intention. In sum, this study contributes to the literature by providing insights for applying general ethics and theory of planned behavior to explain consumers' BYOB behavior. The results also provide policy makers guidelines regarding BYOB. Managerial implications and research limitations are discussed at the end of this paper.
\end{abstract}

Keywords: sustainability; bring your own shopping bags; general theory of marketing ethics; theory of planned behavior

\section{Introduction}

In the last few decades, the public concern for the environment has kept increasing and emerged as an issue with global significance [1-3]. Such concerns have led to great changes in consumer attitudes and behaviors toward sustainability $[4,5]$. Definitions of "sustainability" vary, but most revolve around the idea of preserving the environment for future generations [6]. In this vein, sustainable consumption refers to purchase, use, and disposal of products in a manner which reduces environmental harms [7]. Despite the increasing salience for being greener (due to, for example, climate change and environmental legislation) [8], existing studies on sustainable consumption have focused mainly on organic food consumption [9-12], recycling [13,14] and other green behaviors [2,7,15].

Although consumers may be aware of the importance of sustainability and are willing to adopt the greener option when being surveyed, the actual adoption rate is surprisingly low [1]. In fact, the literature indicates an intention-behavior gap regarding to green consumption [16,17]. Consumers may pretend to adopt the greener option when being surveyed to cater to the public expectation but do not necessarily adopt the greener action in practice. Take plastic bags as an example, although most consumers are aware that plastic bags endanger the environment, unfortunately, many consumers would still choose plastic bags instead of BYOB (i.e., Bring Your Own Shopping Bags) $[18,19]$. This is probably because plastic bags are convenient and easy to access $[20,21]$. However, plastic bags lead to serious threats to the environment [22-24]. It is one of the world's most frequently used and heavily consumed products [23-25], but most plastic bags are disposed of after single usage [26,27]. Degraded 
plastic bags could release toxic gas into the air, and contaminate the agricultural soil and water [26,28]. Moreover, most plastic bags are not fully biodegraded, but break into smaller pieces. When consumed by animals, suffocation and death could occur [28,29]. In addition, the lightweight design causes plastic bags to travel easily by air and water, creating fields of litter and clogging sewers [28].

Based on the above descriptions, there is a need for academic research to better understand why consumers would choose plastic bags over BYOB. A brief review on the literature suggests that existing research on sustainability focuses on topics such as green energy [30,31], recycling [13,14,32], and organic food consumption [10-12,33,34]. To our surprise, few studies tried to explore the BYOB issue $[18,24,35]$. In the existing studies on BYOB, most studies focus on the practical issues such as the number of plastic bags consumed or government policy on BYOB. Only few studies actually focused on the academic perspective (e.g., consumers' intention on BYOB). Among the exceptions, one particular study is Chan and coworkers' (2008) research. Based on Chan and coworkers' (2008) research, the present study aims to expand their model with the ethics perspective, or the deontological evaluation and teleological evaluation [36]. Based on the integrative model proposed, academics would have a better understanding regarding to consumers' BYOB behavior.

In other words, this study integrated Hunt and Vitell's (1986) ethics perspective (i.e., the H-V model) and the Theory of Planned Behavior (TPB) on consumers' BYOB behavior. Previous research has applied the TPB theory in various contexts, but none has applied it on BYOB, they did not import the ethics theory perspective on BYOB. The $\mathrm{H}-\mathrm{V}$ model has drawn increasing attention from academics on ethical consumption recently, as it is believed to play a critical role in consumers' decision-making process. Thus, this study argues that ethics theory is a neglected factor in existing studies and should be included in the literature. The rest of this paper is organized as follows. This study draws on relevant literature in Section 2. On the ethics perspective and TPB, Section 3 develops the hypotheses and proposes an integrative model. In the Section 4, this study presents the research design, measures and data collection. The results are discussed in Section 5. Section 6 summarizes the findings and provides research limitations.

\section{Theoretical Underpinning}

\subsection{General Theory of Marketing Ethics}

In the ethics literature, prior research applies moral philosophies as the theory framework to explain individual's decision-making process with ethical dilemmas [36]. Hunt and Vitell's (1986) General Theory of Marketing Ethics is considered as one of the representative in ethics theory, since it posits that an individual's ethical judgment is a function of his/her deontological evaluation (DE) and teleological evaluation (TE) [37]. Deontological evaluation is defined as an individual who applies his/her norms on the alternatives without considering its following consequences [37,38]. DE suggests that an individual has the duty to do things that are inherently right, such as BYOB [29]. In addition, TE refers to an individual's evaluation of the total of goodness versus badness likely to be perceived by each alternative and subsequent behavior [38,39]. In the literature, numerous studies have supported the influence of DE and TE on consumer's decision-making process [40]. For example, Yoon (2011) adopted both DE and TE to explain individual's decision-making process [36]. Similar findings have been reported in Mayo and Mark's [41] study, which indicates that both DE and TE have a significant impact on consumer's ethical judgments. Overall, the literature verifies the critical role both DE and TE played in individual's decision-making process.

\subsection{Theory of Planned Behavior}

The Theory of Reasoned Action (TRA) proposes that an individual's behavior is determined by his/her intention [42,43]. TRA proposes two major antecedents of behavioral intention: subjective norm and consumer's attitude towards the behavior [43]. Due to the limitations of TRA [44,45], scholars later propose TPB with an additional factor: perceived behavioral control (PBC) [46,47]. PBC refers to 
an individual's perception of his/her ability to perform certain behavior [44,45]. TPB is applied in the sustainable consumption literature frequently, such as studies on organic food consumption [48,49], fair trade products [45], and with green marketing [50].

\section{Hypothesis Development}

Figure 1 presents the overall conceptual framework and delineates the proposed relationships among the constructs in this study.

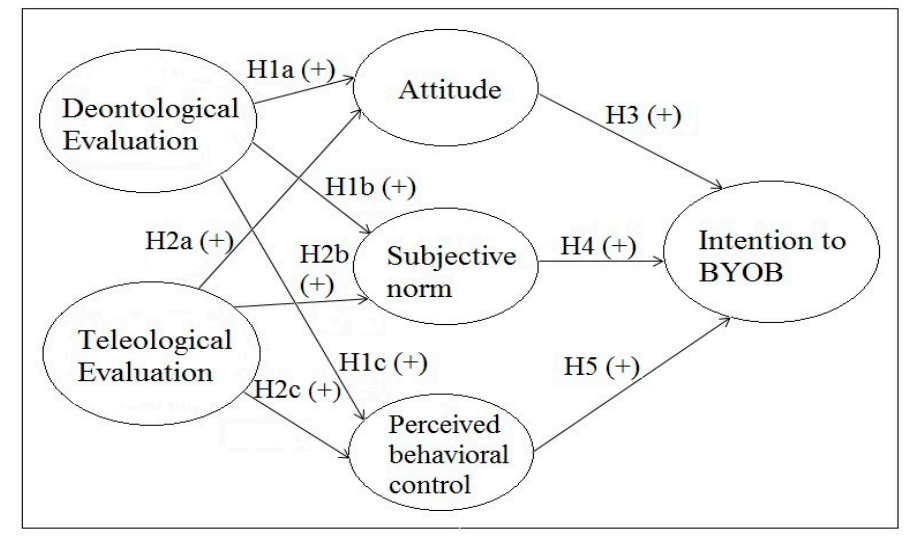

Figure 1. Research model.

3.1. The Positive Relationship between Deontological Evaluation and Consumer's Attitude, Subjective Norm, and Perceived Behavioral Control

The H-V model identifies DE as the inherent righteousness of a behavior through personal values [37]. It refers to a person's obligation to perform/not perform an action [36,51]. Accordingly, a deontological consumer would act based on his/her belief [52]. In the literature, a recent study discusses consumer's willingness to pay a premium for ethical fashion [53], which means clothing made under ethical/green regulations. In the BYOB setting, BYOB is the greener option for consumers to adopt since it could decrease environmental pollution and enhance sustainability. Thus, for consumers who hold a DE belief on sustainability, BYOB would be considered as an obligation that needs to be performed because it is the "right" thing to do. The TPB theory could reinforce the statement since it states that belief could shape consumer's attitude, norms, and perceived behavior control [43]. In TPB, attitude means an individual's overall favorableness for a specific behavior [43,44]; subjective norms refer to perceived social pressure to perform a specific behavior [5]; and perceived behavioral control means perceived ease/difficulty in implementation [54]. Accordingly, consumers with DE orientation would be more likely to generate a higher level of favorableness towards BYOB, which, in accordance with prior studies [33,55], could be interpreted as a higher attitude on BYOB. Similarly, consumers with DE orientation would be more likely to perceive the social pressure on BYOB from others since it is considered as a prevailing environmental belief [38]. Thus, it is likely that consumers with DE orientation would hold higher subjective norm on BYOB. Similarly, consumers with DE orientation are more likely to be perceived with the ability to perform BYOB since consumers with DE orientation are stronger believers, which could lead to higher faith in their ability on BYOB [38]. Thus, we argue that $\mathrm{DE}$ is also likely to influence perceived behavioral control. Accordingly, the following hypotheses in the BYOB context are formulated:

Hypothesis 1 (H1a). Deontological evaluation has a positive influence on attitude.

Hypothesis 1 (H1b). Deontological evaluation has a positive influence on subjective norm.

Hypothesis 1 (H1c). Deontological evaluation has a positive influence on perceived behavioral control. 


\subsection{The Positive Relationship between Teleological Evaluation and Green Consumers' Attitude,} Subjective Norm, and Perceived Behavioral Control

Another central feature in the $\mathrm{H}-\mathrm{V}$ model is how individuals apply a teleological perspective to resolve an ethical dilemma [56]. According to Hunt and Vasquez-Parraga (1993) [39], TE could be explained as the prediction of the consequences of behavior; estimation of the probabilities of consequences; and assessment of the importance of stakeholders involved. The TE perspective assesses the goodness/badness of the consequences which may result from the adoption of each possible alternative $[37,56]$. That is, an individual with TE orientation would decide to act on a certain way after weighing all the possibilities and consequences [41,52]. Based on this, it is possible for $a$ TE oriented consumer to adopt BYOB if he/she believes that BYOB is the better option. Following this, consumers with TE orientation would believe that $\mathrm{BYOB}$ is better since it can do good to the majority of the stakeholders (i.e., in this case, the other consumers, the society, the wild animals, and other related groups), when compared to the adoption of plastic bags. As a result, consumers with TE orientation would be more likely to generate a higher level of attitude towards BYOB; to perceive the social pressure on BYOB; and to be perceived that they can perform BYOB. This statement could be reinforced by the TPB theory which indicates the casual relationship between belief and attitude, social norm, and perceived behavioral control [57]. Thus, this study postulates that consumers with higher TE orientation could generate higher attitude, subjective norm, and perceived behavioral control on BYOB. Accordingly, the following hypotheses were proposed:

Hypothesis 2 (H2a). Teleological evaluation has a positive impact on attitude.

Hypothesis 2 (H2b). Teleological evaluation has a positive impact on subjective norm.

Hypothesis $2 \mathbf{( H 2 c ) . ~ T e l e o l o g i c a l ~ e v a l u a t i o n ~ h a s ~ a ~ p o s i t i v e ~ i m p a c t ~ o n ~ p e r c e i v e d ~ b e h a v i o r a l ~ c o n t r o l . ~}$

\subsection{The Positive Relationship between Consumers' Attitude and BYOB Intention}

Consumers' attitude is a key determinant of behavioral intention [47,57]. It refers to an individual's feeling of favor/disfavor to perform a certain behavior [58]. The TPB theory states that the more favorably an individual evaluates to perform a certain behavior, the more likely the individual would intend to perform that behavior $[43,58]$. In the literature, numerous studies support the argument, or a positive relationship between consumers' attitude and intention. For instance, Ma and Littrell [45] suggested that young US female consumers' attitude towards fair trade products is positively related to their purchase intention. Similarly, Wan and Cheung [42] found that university students' higher attitude towards recycling leads to higher intention on recycling. In sum, the literature indicates that consumers with stronger attitude towards sustainability are more willing to adopt green options. Although the relationship between consumer's attitude and BYOB intention has not been verified in the literature, it can be postulated that the link would be positive, based on the similar findings in the literature $[18,55,59]$. Thus, it is hypothesized that:

Hypothesis 3 (H3). Consumers' attitude towards BYOB has a positive impact on BYOB intention.

\subsection{The Positive Relationship between Consumers' Subjective Norm and BYOB Intention}

Fishbein and Ajzen (1975) initially described subjective norm as one of the main predictors of behavioral intentions when examining individuals' decision-making processes [58]. It is referred to as the social pressure an individual perceives to perform a certain behavior $[42,60]$. In the literature, numerous studies consistently indicate that higher subjective norm leads to higher intention $[46,54,55]$. For instance, a recent study on consumer's intention to stay at green hotels suggests that higher subjective norm leads to higher intention to stay at a green hotel [61]. This argument is further 
reinforced by another study which cross examined the subjective norm-intention relationship in several markets [50]. Since BYOB is becoming a major norm in the society [35], consumers are more likely to perceive the norm of $\mathrm{BYOB}$, which would consequently lead to higher intention to BYOB. Thus, it is argued:

Hypothesis 4 (H4). Consumers' subjective norm has a positive impact on BYOB intention.

\subsection{The Positive Relationship between Green Consumers' Perceived Behavioral Control and BYOB Intention}

In the TPB theory, perceived behavioral control is another major element [58]. It concerns an individual's perceived ease/difficulty in implementing a certain behavior in question [54]. TPB theory states that, if an individual perceives higher behavioral control in himself/herself, he/she is likely to generate higher intention [47]. In the literature, the impact of perceived behavioral control on consumers' behavioral intention has been verified by many studies $[34,62]$. For example, a prior study suggests that higher perceived behavioral control leads to higher intention on organic food consumption [34]. Since BYOB is considered a green option similar to organic food consumption [35,63], it can be argued that such a relationship could also exist in the BYOB setting. That is, higher perceived behavioral control on BYOB leads to higher intention on BYOB. Based on the aforementioned findings, it is hypothesized that:

Hypothesis 5 (H5). Perceived behavioral control has a positive impact on consumer's BYOB intention.

\section{Methods}

\subsection{Questionnaire Design}

A self-administered questionnaire was developed to verify the hypotheses and research framework. To ensure content validity, all variables in this study were measured by scalable items adapted from previous studies, and the content of questionnaire items were revised properly in the BYOB context. The questionnaire consisted of seven sections: deontological evaluation, teleological evaluation, attitude, subjective norm, perceived behavioral control, BYOB intention, and demographic information. In the beginning of the questionnaire, a definition of BYOB was informed to respondents. An additional item was designed to screen participants with BYOB behavior in the last sixth months only. Participants that never BYOB before nor in the last six months were deleted from further analysis. This approach ensured that each participant has both knowledge and experience of BYOB. The questionnaire was translated from English into Chinese and was reviewed by native speakers for potential syntax errors. Several academics and experts of the subject were invited to review the questionnaire before distribution, to assure content validity. Subsequently, a pretest was conducted to ensure the quality and the clarity of each construct. Based on the responses from 30 respondents from a variety of job positions and industries, few minor changes were adjusted. Overall, the pretest suggested that the questionnaire is understandable and clearly communicated.

\subsection{Definitions and Measurements of the Constructs}

Five-point scales were used for all psychometric measures and, where nothing else is mentioned, response categories ranged from $1=$ "strongly disagree" to $5=$ "strongly agree". Following previous research [37,39], DE was operationalized as the belief that an act is morally right, regardless of the consequences of the act. Adopting the definition, this study follows prior studies' items to measure DE [18]. Similarly, TE was defined as the belief that an act is good/bad based on the consequences of the act [37,39]. In operationalization, seven items were adapted based on existing literature [18]. Moreover, this study follows prior study by defining attitude as the level of favorable/unfavorable evaluation of a certain behavior [55]. Participants rated their general attitudes toward BYOB using 
items based on prior studies $[33,46]$. Subjective norm was defined as the perceived social pressure to accept/act in a certain behavior [62]. Six items from prior studies [5,64] were adapted for the survey. In addition, this study followed Wan and coworkers' (2012) definition on perceived behavioral control as "the perception of an individual's ability to perform a certain behavior" [42]. In operationalization, seven items were adapted from prior studies to measure perceived behavioral control $[18,54]$. Finally, BYOB intention was adapted from prior study as "the willingness of an individual to BYOB [62]". Scales proposed by prior studies $[33,65]$ were used for the measurement of BYOB intention.

\subsection{Data Collection and the Sample Profile}

The survey was conducted in Taiwan for several reasons [63]. Taiwan is densely populated and the environment is heavily polluted [66], which made BYOB an official policy and most consumers are aware of it [67]. According to the Taiwan Environmental Protection Administration, billions of plastic bags are consumed annually on the island. As a result, plastic bag levies are imposed on merchants to restrain usage, and encourage consumers to BYOB [65]. Therefore, a study of BYOB behavior in Taiwan is not only theoretical, but also of great practical value, especially for policy makers. The survey questionnaire was distributed by email to consumers at urban areas in Taipei, between November 2015 and February 2016. Attached in the email in electronic form, each respondent received a cover letter that explained the purpose of this research and guaranteed the anonymity to erase privacy concerns. It also encouraged respondents to answer the questions as honestly as possible since there was no right or wrong answer in it. Since the questionnaire was responded via Internet, it is assumed that the majority respondents filled the questionnaire in private via their personal computers, notebooks, or even mobile digital devices such as smart phones or tablets. Research suggests that individuals are likely to suffer from conformity pressures when others are present [15]. In this survey, the internet was used as a channel to collect data so that the majority respondents could at least, to some extent, minimize the chances of social desirability bias. The sample was selected based on convenience sampling, since the majority of consumers in Taiwan have BYOB experience due to government promotion and support. Each respondent was asked to provide general demographic information, including gender, age, educational level, income, and marital status. Finally, 680 questionnaires were collected, and 601 were used in the analysis. Incomplete and unreliable responses (e.g., those who had no practice of BYOB before or within the last six months) were dropped.

Table 1 presents the demographic information. The sample consisted of $30.12 \%$ male and $69.88 \%$ female. The majority of respondents were between 20 and 29 years old $(67.89 \%)$, $86.69 \%$ of respondents were single, $11.81 \%$ were married, and $77.54 \%$ of respondents obtained at a university degree. For occupation, the largest group was comprised of students (61.73\%). More than half of the respondents had an average monthly income of 20,000 NT dollars (1 U.S. dollar $=33$ NT dollars) or below (55.41\%). Regarding BYOB frequency, 26\% had BYOB once a week, followed by $25.5 \%$ respondents who BYOB once a month. Thus, this study concludes that young and unmarried females with a bachelor's degree are the majority of the sample. 
Table 1. Demographic characteristics of respondents.

\begin{tabular}{|c|c|c|c|}
\hline Characteristic & Categories & Frequency & Percentage \\
\hline \multirow{2}{*}{ Gender } & Male & 181 & $30.12 \%$ \\
\hline & Female & 420 & $69.88 \%$ \\
\hline \multirow{6}{*}{ Age } & 20 or under & 96 & $15.97 \%$ \\
\hline & $20-29$ & 408 & $67.89 \%$ \\
\hline & $30-39$ & 54 & $8.99 \%$ \\
\hline & $40-49$ & 19 & $3.16 \%$ \\
\hline & $50-59$ & 16 & $2.66 \%$ \\
\hline & Above 60 & 8 & $1.33 \%$ \\
\hline \multirow{3}{*}{ Education } & High school & 15 & $2.50 \%$ \\
\hline & Bachelor's degree & 466 & $77.54 \%$ \\
\hline & Postgraduate and above & 120 & $19.97 \%$ \\
\hline \multirow{6}{*}{ Occupation } & Student & 371 & $61.73 \%$ \\
\hline & Blue-collar worker & 1 & $0.17 \%$ \\
\hline & Office worker & 144 & $23.96 \%$ \\
\hline & Managerial employee & 41 & $6.82 \%$ \\
\hline & Civil servant & 4 & $0.67 \%$ \\
\hline & Other & 40 & $6.66 \%$ \\
\hline \multirow{4}{*}{ Marital Status } & Single & 521 & $86.69 \%$ \\
\hline & Married & 71 & $11.81 \%$ \\
\hline & Divorced & 4 & $0.67 \%$ \\
\hline & Living with partner & 5 & $0.83 \%$ \\
\hline \multirow{5}{*}{ Monthly Income } & 20,000 or under & 333 & $55.41 \%$ \\
\hline & $20,001-40,000$ & 131 & $21.80 \%$ \\
\hline & $40,001-60,000$ & 86 & $14.31 \%$ \\
\hline & $60,001-80,000$ & 31 & $5.16 \%$ \\
\hline & 80,001 and above & 20 & $3.33 \%$ \\
\hline \multirow{5}{*}{ BYOB Frequency } & More than once a week & 152 & $25.3 \%$ \\
\hline & Once a week & 156 & $26.0 \%$ \\
\hline & Once in two weeks & 76 & $12.6 \%$ \\
\hline & Once a month & 153 & $25.5 \%$ \\
\hline & Less than once a month & 64 & $10.6 \%$ \\
\hline
\end{tabular}

\subsection{Limitations in Methodology}

Based on the methods regarding data collection, this study suffers from the following potential limitations. Readers should be cautious when generalizing the results into other contexts. First, this study collected data based on a convenience method. The results presented may not accurately catch the total population in Taiwan. For example, the majority respondents hold a bachelor's degree while only $50 \%$ of Taiwanese population have a bachelor's degree. Second, most respondents tended to be younger, when compared with other studies. Literature suggests that younger consumers and senior consumers might hold different attitudes towards sustainability. Third, another important oversight in data collection is the potential impact of descriptive norms. Respondents could pretend to submit their responses based on what is the "desired" answer regardless of their true attitude and intention.

\section{Empirical Results}

\subsection{Reliability and Validity}

The SPSS software package was utilized for statistical analyses, and LISREL was employed to analyze the proposed model. The scales were examined via exploratory factor analysis (EFA) to identify poor fit items, and confirmatory factor analysis (CFA) for measure purification [68]. Based on 
prior study [69], the criteria for acceptable psychometric properties require that: (1) loadings in a CFA exceed 0.70; and (2) loadings are greater than their cross-loadings. Following the criteria, few items were removed from the following analysis. A factor analysis with the remaining items was conducted again and it indicated acceptable results. Reliability was calculated via an examination of Cronbach's alpha coefficients. The results of the reliability analysis suggested the Cronbach's alpha ranges from 0.864 to 0.957 across all measures, which indicated adequate fit [70].

Convergent validity was examined by calculating the average variance extracted (AVE) value of each construct [69]. The results in Table 2 indicated that all AVE values were above 0.50 (range $0.55-0.81$ ), which suggested adequate convergent validity. Two criteria were applied to examine the discriminant validity [69]: (1) the square root of AVE (i.e., leading diagonal in Table 3) should be larger than the inter-construct correlation; and (2) indicators should load more strongly on their corresponding construct than on other constructs in the model. The results in the factor analysis and Table 3 indicated adequate fit. In sum, the measurement results were satisfactory and suggested to proceed with the evaluation of the structural model.

Table 2. Validity and reliability of the reflective constructs.

\begin{tabular}{|c|c|c|c|c|c|c|}
\hline Constructs & Indicator & $\begin{array}{l}\text { Standardized } \\
\text { Factor Loading }\end{array}$ & $t$-Value & $\begin{array}{l}\text { Measurement } \\
\text { Error }\end{array}$ & CR & AVE \\
\hline \multirow{4}{*}{ Deontological evaluation } & DE1 & 0.77 & - & 0.41 & \multirow{4}{*}{0.83} & \multirow{4}{*}{0.55} \\
\hline & DE2 & 0.74 & 16.01 & 0.46 & & \\
\hline & DE3 & 0.73 & 23.05 & 0.47 & & \\
\hline & DE4 & 0.72 & 16.50 & 0.48 & & \\
\hline \multirow{3}{*}{ Teleological evaluation } & TE1 & 0.92 & - & 0.15 & \multirow{3}{*}{0.92} & \multirow{3}{*}{0.78} \\
\hline & TE2 & 0.90 & 33 & 0.19 & & \\
\hline & TE3 & 0.83 & 28.17 & 0.31 & & \\
\hline \multirow{3}{*}{ Attitude } & AT3 & 0.81 & - & 0.35 & \multirow{3}{*}{0.82} & \multirow{3}{*}{0.60} \\
\hline & AT5 & 0.72 & 19.25 & 0.49 & & \\
\hline & AT7 & 0.79 & 18.61 & 0.38 & & \\
\hline \multirow{3}{*}{ Subjective norm } & SN3 & 0.91 & - & 0.18 & \multirow{3}{*}{0.91} & \multirow{3}{*}{0.77} \\
\hline & SN4 & 0.90 & 31.64 & 0.19 & & \\
\hline & SN5 & 0.83 & 27.27 & 0.32 & & \\
\hline \multirow{3}{*}{$\begin{array}{l}\text { Perceived behavioral } \\
\text { control }\end{array}$} & PBC2 & 0.89 & - & 0.22 & \multirow{3}{*}{0.92} & \multirow{3}{*}{0.79} \\
\hline & PBC4 & 0.89 & 29.03 & 0.21 & & \\
\hline & PBC5 & 0.89 & 29 & 0.21 & & \\
\hline \multirow{5}{*}{ Intentional Behavior } & IB1 & 0.88 & - & 0.23 & \multirow{5}{*}{0.95} & \multirow{5}{*}{0.81} \\
\hline & IB2 & 0.88 & 31.53 & 0.22 & & \\
\hline & IB4 & 0.93 & 35.57 & 0.13 & & \\
\hline & IB5 & 0.88 & 31.56 & 0.22 & & \\
\hline & IB6 & 0.92 & 34.96 & 0.15 & & \\
\hline
\end{tabular}

Table 3. Discriminant validity and correlation of the latent variable scores.

\begin{tabular}{ccccccccc}
\hline Constructs & Mean & SD & DE & TE & AT & SN & PBC & IN \\
\hline DE & 4.00 & 0.74 & 0.73 & & & & & \\
TE & 4.31 & 0.72 & $0.62^{* * *}$ & 0.88 & & & & \\
AT & 3.66 & 0.85 & $0.49^{* * *}$ & $0.45^{* * *}$ & 0.77 & & & \\
SN & 3.562 & 0.82 & $0.37^{* * *}$ & $0.35^{* * *}$ & $0.60^{* * *}$ & 0.87 & & \\
PBC & 4.09 & 0.77 & $0.53^{* * *}$ & $0.57^{* * *}$ & $0.56^{* * *}$ & $0.51^{* * *}$ & 0.88 & \\
IB & 4.11 & 0.79 & $0.57^{* * *}$ & $0.58^{* * *}$ & $0.62^{* * *}$ & $0.49^{* * *}$ & $0.81^{* * *}$ & 0.89 \\
\hline
\end{tabular}

Notes: Square root of AVE presented on the diagonal; ${ }^{* * *} p<0.01$. 


\subsection{Structural Model}

The effects proposed in the model and their significance were analyzed via structural equation modeling (SEM) [71]. Figure 2 depicts the results of the model and Table 4 indicates the model fit statistics. Following Bagozzi and Yi, the overall fit in Table 4 (GFI $=0.90$, RMSEA $=0.7$, NFI $=0.98$, $\mathrm{CFI}=0.98)$ suggested good fit [72]. Table 5 shows that $\mathrm{DE}$ exerted a positive direct effect on attitude ( $\beta=0.66, t=7.79)$, subjective norm $(\beta=0.51, t=6.23)$, and perceived behavioral control $(\beta=0.57$, $t=7.89)$, respectively. TE also exerted a positive direct effect on perceived behavioral control $(\beta=0.20$, $t=3.21)$, while its influence on attitude $(\beta=0.08, t=1.12)$ and subjective norm $(\beta=0.00, t=0.03)$ was not supported. In addition, the results suggested that attitude exerted a positive direct effect on BYOB intention $(\beta=0.32, t=6.56)$, and perceived behavioral control also exerted a positive direct effect on BYOB intention ( $\beta=0.72, t=19.44)$, thereby is consistent with prior studies $[42,44,73]$. Finally, the relationship between subjective norm and BYOB intention was not supported ( $\beta=-0.07$, $t=1.88)$. The structural analysis results are further summarized in Table 5.

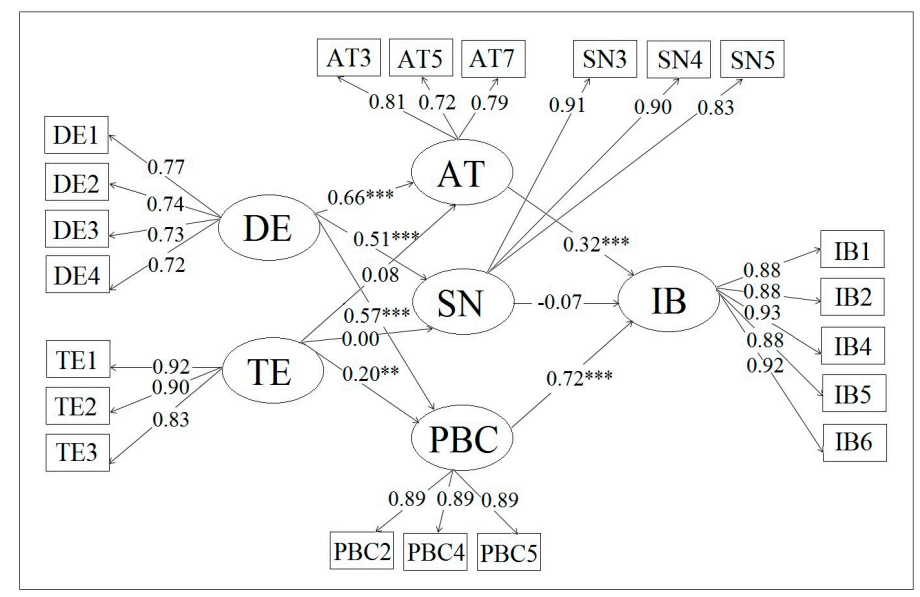

Figure 2. Structural model results. ${ }^{* *} p<0.05,{ }^{* * *} p<0.01$.

Table 4. Model fit statistics.

\begin{tabular}{cccc}
\hline Fit Indices & Cut-Off Value & Fit Statistics & Evaluation \\
\hline$\chi^{2} / \mathbf{d f}$ & $2 \sim 5$ & 3.97 & Satisfactory \\
GFI & $>0.9$ & 0.90 & Satisfactory \\
AGFI & $>0.8$ & 0.87 & Satisfactory \\
RMSEA & $<0.08$ & 0.07 & Satisfactory \\
NFI & $>0.9$ & 0.98 & Satisfactory \\
CFI & $>0.9$ & 0.98 & Satisfactory \\
IFI & $>0.9$ & 0.98 & Satisfactory \\
\hline
\end{tabular}

Table 5. Testing results of the structural model.

\begin{tabular}{cccc}
\hline Hypothesis & $\beta$ & $t$ Statistics & Result \\
\hline H1a & 0.66 & $7.79^{* * *}$ & Supported \\
H1b & 0.51 & $6.23^{* * *}$ & Supported \\
H1c & 0.57 & $7.89^{* * *}$ & Supported \\
H2a & 0.08 & 1.12 & Not supported \\
H2b & 0.00 & 0.03 & Not supported \\
H2c & 0.20 & $3.21^{* *}$ & Supported \\
H3 & 0.32 & $6.56^{* * *}$ & Supported \\
H4 & -0.07 & -1.88 & Not supported \\
H5 & 0.72 & $19.44^{* * *}$ & Supported \\
\hline \multicolumn{4}{c}{}
\end{tabular}




\section{Discussion}

This study proposed and tested an integrative model from TPB and ethical perspective underlying BYOB context. The results indicated that DE has a positive impact on attitude, subjective norm, and perceived behavioral control. TE exerted a positive direct effect on perceived behavioral control, but not on attitude and subjective norm. In addition, both attitude and perceived behavioral control exerted a positive effect on BYOB intention. Surprisingly, subjective norm did not exert a positive effect on BYOB intention, which was inconsistent with prior findings [18]. Below, this study generates several important academic and practical implications.

\subsection{Theoretical Application}

Several theoretical implications were able to be derived from the empirical results. First, this study provides empirical evidence via extending Chan and coworkers' (2008) and Lam and Chen's (2006) work on BYOB. Chan and coworkers' (2008) study explains how consumers' BYOB behavior is influenced via ethical concerns. This study contributes to the literature by integrating ethics theory with TPB in conjunction to examine consumer's willingness to BYOB. The application of the TPB in the context of BYOB has been demonstrated by the results of this study. BYOB intentions were influenced by consumers' attitude, and perceived behavioral control. Surprisingly, the results suggested that TE is not a major factor in consumers' BYOB decision-making process. This could be contributed to the place of this survey. From the historical perspective, the advancement of economics and modernization in Taiwan was only decades ago. Some consumers in Taiwan would be still following Chinese tradition on money-making and ignore other stakeholder groups' interests, such as BYOB. This could explain why TE played a limited role in the proposed model. This argument could be further reinforced from a cultural perspective. According to Hofstede's cultural dimension theory [74-76], people in Taiwan are highly masculine oriented. This means, culturally speaking, that consumers in Taiwan would focus on money-making and the weekly working hours in Taiwan are also among the highest in the world. People usually purchase take-out meals from restaurants and do not have time to cook for themselves due to the pressures from work. Thus, consumers in Taiwan could focus on their interest first and choose to ignore or do not have time to assess other stakeholders' interests.

Another insignificant relationship is subjective norm towards BYOB intention. Again, one possible explanation could be contributed to the cultural dimension theory. In Hofstede's cultural dimension theory, local consumers in Taiwan were considered as high power-distance oriented. Despite the governments' high promotion of BYOB, consumers in Taiwan may not feel comfortable to express their true opinion regarding BYOB due to high power-distance between the government and individuals. This could explain why the societal norm on BYOB was already well established but did not exert a positive direct effect on BYOB intention.

\subsection{Implications for Practitioners}

This study's findings have generated several implications for practitioners. First, the results suggest that both attitude and perceived behavioral control exerted a positive direct effect BYOB intention, while subjective norm did not. Thus, policy makers should spend resources on shaping consumers' attitude and perceived behavioral control. Using resources on getting a norm of BYOB would result in limited efforts, when compared to attitude and perceived behavioral control. From a practical point of view, the government should reshape consumer's attitude on BYOB by holding seminars or making commercials on TV since it is related to intention. In addition, the government should invest in activities that would make consumers think BYOB is easy to access and everyone can have control over himself/herself on BYOB. 


\subsection{Directions for Future Research}

Despite its contributions, this study is not without limitations. First, the theoretical basis of this study is not novel. While it is justified to first explore BYOB with ethics perspective and TPB, future investigations with other novel theories will help further assess our understanding on BYOB. Second, the study was limited to mainly young consumers. Future research can expand this study by including both young consumers and senior consumers, and by comparing the findings from the two groups' perspective since the literature suggests that there is a significant difference between the two group's attributes. Third, this study focused on consumers' intention only. Thus, we encourage future studies to add and explore the impact of other potential influencing factors in a more macro perspective, such as the influence of the government, the role of shopkeepers, and some macro environmental factors such as ecosystems and infrastructures that may influence BYOB intentions. Finally, future studies could consider to add moderators or new variables to further assess the external validity of the proposed model.

Author Contributions: Both authors contribute equally to the paper.

Acknowledgments: The authors thank two anonymous reviews sincerely for their insightful comments.

Conflicts of Interest: The authors declare no conflict of interest.

\section{References}

1. Young, W.; McDonald, S.; Oates, C.J. Sustainable consumption: Green consumer behaviour when purchasing products. Sustain. Dev. 2010, 18, 20-31. [CrossRef]

2. Gilg, A.; Barr, S.; Ford, N. Green consumption or sustainable lifestyles? Identifying the sustainable consumer. Futures 2005, 37, 481-504. [CrossRef]

3. Chang, C. Feeling Ambivalent about Going Green. J. Advert. 2011, 40, 19-32. [CrossRef]

4. Akehurst, G.; Afonso, C.; Martins, G.H. Re-examining green purchase behaviour and the green consumer profile: New evidences. Manag. Decis. 2012, 50, 972-988. [CrossRef]

5. Albayrak, T.; Aksoy, S.; Caber, M. The effect of environmental concern and scepticism on green purchase behaviour. Mark. Intell. Plan. 2013, 31, 27-39. [CrossRef]

6. Ferrell, O.C.; Fraedrich, J.; Ferrell, L. Business Ethics: Ethical Decision Making \& Cases; Cengage Learning: Boston, MA, USA, 2014.

7. Rakic, M.; Rakic, B. Sustainable lifestyle marketing of individuals: The base of sustainability. Amfiteatru Econ. 2015, 17, 891-908.

8. Shahnaei, S. The impact of individual differences on green purchasing of Malaysian consumers. Int. J. Bus. Soc. Sci. 2012, 3, 132-140.

9. Thøgersen, J.; de Barcellos, M.D.; Perin, M.G.; Zhou, Y. Consumer buying motives and attitudes towards organic food in two emerging markets: China and Brazil. Int. Mark. Rev. 2015, 32, 389-413. [CrossRef]

10. Chen, J.; Lobo, A. Organic food products in China: Determinants of consumers' purchase intentions. Int. Rev. Retail Distrib. Consum. Res. 2012, 22, 293-314. [CrossRef]

11. Aertsens, J.; Verbeke, W.; Mondelaers, K.; Van Huylenbroeck, G. Personal determinants of organic food consumption: A review. Br. Food J. 2009, 111, 1140-1167. [CrossRef]

12. Chang, S.H.; Chang, C.W. Tie Strength, Green Expertise, and Interpersonal Influences on Organic Food Purchase in an Emerging Market. Br. Food J. 2017, 119, 284-300. [CrossRef]

13. Vining, J.; Ebreo, A. What Makes a Recycler? A Comparison of Recyclers and Nonrecyclers. Environ. Behav. 1990, 22, 55-73. [CrossRef]

14. Hopper, J.R.; Nielsen, J.M. Recycling as Altruistic Behavior: Normative and Behavioral Strategies to Expand Participation in a Community Recycling Program. Environ. Behav. 1991, 23, 195-220. [CrossRef]

15. Chang, S.-H. The Influence of Green Viral Communications on Green Purchase Intentions: The Mediating Role of Consumers' Susceptibility to Interpersonal Influences. Sustainability 2015, 7, 4829. [CrossRef]

16. Vermeir, I.; Verbeke, W. Sustainable Food Consumption: Exploring the Consumer "Attitude-Behavioral Intention" Gap. J. Agric. Environ. Ethics 2006, 19, 169-194. [CrossRef] 
17. Durif, F.; Roy, J.; Boivin, C. Could Perceived Risks Explain the 'Green Gap' in Green Product Consumption? Available online: https:/ / escholarship.org/uc/item/1p65c93r (accessed on 24 May 2018).

18. Chan, R.Y.; Wong, Y.; Leung, T.K. Applying ethical concepts to the study of "green" consumer behavior: An analysis of Chinese consumers' intentions to bring their own shopping bags. J. Bus. Ethics 2008, 79, 469-481. [CrossRef]

19. Ar1, E.; Yilmaz, V. Consumer attitudes on the use of plastic and cloth bags. Environ. Dev. Sustain. 2017, 19, 1219-1234. [CrossRef]

20. Ellis, S.; Kantner, S.; Saab, A.; Watson, M.; Kadonaga, L. Plastic Grocery Bags: The Ecological Footprint; Student Publications, VIPIRG Publications; University of Victoria: Victoria, BC, Canada, 2005; Volume 3050, pp. 1-19.

21. Boone, L.E.; Kurtz, D.L. Contemporary Business 2010 Update; John Wiley \& Sons: Hoboken, NJ, USA, 2009.

22. Convery, F.; McDonnell, S.; Ferreira, S. The most popular tax in Europe? Lessons from the Irish plastic bags levy. Environ. Resour. Econ. 2007, 38, 1-11. [CrossRef]

23. Sharp, A.; Høj, S.; Wheeler, M. Proscription and its impact on anti-consumption behaviour and attitudes: The case of plastic bags. J. Consum. Behav. 2010, 9, 470-484. [CrossRef]

24. Zen, I.S.; Ahamad, R.; Omar, W. No plastic bag campaign day in Malaysia and the policy implication. Environ. Dev. Sustain. 2013, 15, 1259-1269. [CrossRef]

25. Lu, L.-T.; Hsiao, T.Y.; Shang, N.C.; Yu, Y.H.; Ma, H.W. MSW management for waste minimization in Taiwan: The last two decades. Waste Manag. 2006, 26, 661-667. [CrossRef] [PubMed]

26. Adane, L.; Muleta, D. Survey on the usage of plastic bags, their disposal and adverse impacts on environment: A case study in Jimma City, Southwestern Ethiopia. J. Toxicol. Environ. Health Sci. 2011, 3, 234-248.

27. Alam, O.; Wang, S.; Lu, W. Heavy metals dispersion during thermal treatment of plastic bags and its recovery. J. Environ. Manag. 2018, 212, 367-374. [CrossRef] [PubMed]

28. Clapp, J.; Swanston, L. Doing away with plastic shopping bags: International patterns of norm emergence and policy implementation. Environ. Politics 2009, 18, 315-332. [CrossRef]

29. Roach, J. Are Plastic Grocery Bags Sacking the Environment? National Geographic News, 2 September 2003.

30. Roe, B.; Teisl, M.F.; Levy, A.; Russell, M. US consumers' willingness to pay for green electricity. Energy Policy 2001, 29, 917-925. [CrossRef]

31. Hansla, A.; Gamble, A.; Juliusson, A.; Gärling, T. Psychological determinants of attitude towards and willingness to pay for green electricity. Energy Policy 2008, 36, 768-774. [CrossRef]

32. Granzin, K.L.; Olsen, J.E. Characterizing Participants in Activities Protecting the Environment: A Focus on Donating, Recycling, and Conservation Behaviors. J. Public Policy Mark. 1991, 10, 1-27.

33. Soyez, K.; Francis, P.J.N.; Smirnova, M.M. How individual, product and situational determinants affect the intention to buy and organic food buying behavior: A cross-national comparison in five nations. Markt 2012, 51, 27-35. [CrossRef]

34. Nuttavuthisit, K.; Thøgersen, J. The Importance of Consumer Trust for the Emergence of a Market for Green Products: The Case of Organic Food. J. Bus. Ethics 2015, 140, 323-337. [CrossRef]

35. Karmarkar, U.R.; Bollinger, B. BYOB: How Bringing Your Own Shopping Bags Leads to Treating Yourself and the Environment. J. Mark. 2015, 79, 1-15. [CrossRef]

36. Yoon, C.J. Theory of Planned Behavior and Ethics Theory in Digital Piracy: An Integrated Model. J. Bus. Ethics 2011, 100, 405-417. [CrossRef]

37. Hunt, S.D.; Vitell, S. A general theory of marketing ethics. J. Macromark. 1986, 6, 5-16. [CrossRef]

38. Akaah, I.P. Influence of Deontological and Teleological Factors on Research Ethics Evaluations. J. Bus. Res. 1997, 39, 71-80. [CrossRef]

39. Hunt, S.D.; Vasquez-Parraga, A.Z. Organizational consequences, marketing ethics, and salesforce supervision. J. Mark. Res. 1993, 30, 78-90. [CrossRef]

40. Hunt, S.D.; Vitell, S.J. The General Theory of Marketing Ethics: A Revision and Three Questions. J. Macromark. 2006, 26, 143-153. [CrossRef]

41. Mayo, M.; Marks, L. An empirical investigation of a general theory of marketing ethics. J. Acad. Mark. Sci. 1990, 18, 163-171. [CrossRef]

42. Wan, C.; Cheung, R.; Qiping, S.G. Recycling attitude and behaviour in university campus: A case study in Hong Kong. Facilities 2012, 30, 630-646. [CrossRef]

43. Fishbein, M.; Ajzen, I. Belief, Attitude, Intention and Behaviour: An Introduction to Theory and Research; Addison-Wesley: Boston, MA, USA, 1975; Volume 27. 
44. Chang, M.K. Predicting unethical behavior: A comparison of the theory of reasoned action on the theory of planned behavior. J. Bus. Ethics 1998, 17, 1825-1834. [CrossRef]

45. Ma, Y.J.; Littrell, M.A.; Niehm, L. Young female consumers' intentions toward fair trade consumption. Int. J. Retail Distrib. Manag. 2012, 40,41-63.

46. Chow, W.; Chen, Y. Intended belief and actual behavior in green computing in Hong Kong. J. Comput. Inf. Syst. 2009, 50, 136-141.

47. Ajzen, I. The theory of planned behavior. Organ. Behav. Hum. Decis. Process. 1991, 50, 179-211. [CrossRef]

48. Thanika Devi, J.; Pudaruth, S.; Emmanuelle, N.M.M. Analysing the impact of green marketing strategies on consumer purchasing patterns in Mauritius. World J. Entrep. Manag. Sustain. Dev. 2012, 8, 36-59.

49. Zhou, Y.; Thøgersen, J.; Ruan, Y.; Huang, G. The moderating role of human values in planned behavior: The case of Chinese consumers' intention to buy organic food. J. Consum. Mark. 2013, 30, 335-344. [CrossRef]

50. Kalafatis, S.P.; Pollard, M.; East, R.; Tsogas, M.H. Green marketing and Ajzen's theory of planned behaviour: A cross-market examination. J. Consum. Mark. 1999, 16, 441-460. [CrossRef]

51. Cronan, T.P.; Al-Rafee, S. Factors that influence the intention to pirate software and media. J. Bus. Ethics 2008, 78, 527-545. [CrossRef]

52. Rallapalli, K.C.; Vitell, S.J.; Barnes, J.H. The Influence of Norms on Ethical Judgments and Intentions: An Empirical Study of Marketing Professionals. J. Bus. Res. 1998, 43, 157-168. [CrossRef]

53. Shen, B.; Wang, Y.; Lo, C.K.; Shum, M. The impact of ethical fashion on consumer purchase behavior. J. Fash. Mark. Manag. 2012, 16, 234-245. [CrossRef]

54. Swaim, J.A.; Maloni, M.J.; Napshin, S.A.; Henley, A.B. Influences on Student Intention and Behavior toward Environmental Sustainability. J. Bus. Ethics 2014, 124, 465-484. [CrossRef]

55. Tarkiainen, A.; Sundqvist, S. Subjective norms, attitudes and intentions of Finnish consumers in buying organic food. Br. Food J. 2005, 107, 808-822. [CrossRef]

56. Cole, D.; Sirgy, M.J.; Bird, M.M. How Do Managers Make Teleological Evaluations in Ethical Dilemmas? Testing Part of and Extending the Hunt-Vitell Model. J. Bus. Ethics 2000, 26, 259-269. [CrossRef]

57. Kim, H.Y.; Chung, J.-E. Consumer purchase intention for organic personal care products. J. Consum. Mark. 2011, 28, 40-47.

58. Randall, D.M.; Gibson, A.M. Ethical Decision Making in the Medical Profession: An Application of the Theory of Planned Behavior. J. Bus. Ethics 1991, 10, 111-122. [CrossRef]

59. Cherian, J.; Jacob, J. Green marketing: A study of consumers' attitude towards environment friendly products. Asían Soc. Sci. 2012, 8, 117. [CrossRef]

60. Teng, C.-C.; Wang, Y.-M. Decisional factors driving organic food consumption: Generation of consumer purchase intentions. Br. Food J. 2015, 117, 1066-1081. [CrossRef]

61. Kim, Y.; Han, H. Intention to pay conventional-hotel prices at a green hotel-A modification of the theory of planned behavior. J. Sustain. Tour. 2010, 18, 997-1014. [CrossRef]

62. Wu, S.-I.; Chen, J.-Y. A Model of Green Consumption Behavior Constructed by the Theory of Planned Behavior. Int. J. Mark. Stud. 2014, 6, 119-132. [CrossRef]

63. Lam, S.-P.; Chen, J.-K. What Makes Customers Bring Their Bags or Buy Bags from the Shop? A Survey of Customers at a Taiwan Hypermarket. Environ. Behav. 2006, 38, 318-332. [CrossRef]

64. Al-Swidi, A.; Mohammed Rafiul Huque, S.; Haroon Hafeez, M.; Noor Mohd Shariff, M. The role of subjective norms in theory of planned behavior in the context of organic food consumption. Br. Food J. 2014, 116, 1561-1580. [CrossRef]

65. Lu, L.-C.; Chang, H.-H.; Chang, A. Consumer Personality and Green Buying Intention: The Mediate Role of Consumer Ethical Beliefs. J. Bus. Ethics 2015, 127, 205-219. [CrossRef]

66. Chen, C.-M.; Lin, Y.-L.; Hsu, C.-L. Does air pollution drive away tourists? A case study of the Sun Moon Lake National Scenic Area, Taiwan. Trans. Res. Part D Transp. Environ. 2017, 53, 398-402. [CrossRef]

67. Mokhtar, S.H.; Deng, Y.-S. Identification of Key Forces Influencing Sustainable Development in Taiwan. J. Sustain. Dev. 2015, 8, 174-186. [CrossRef]

68. Gerbing, D.W.; Hamilton, J.G. Viability of exploratory factor analysis as a precursor to confirmatory factor analysis. Struct. Equat. Model. 1996, 3, 62-72. [CrossRef]

69. Fornell, C.; Larcker, D.F. Evaluating structural equation models with unobservable variables and measurement error. J. Mark. Res. 1981, 18, 39-50. [CrossRef]

70. Cronbach, L.J. Coefficient alpha and the internal structure of tests. Psychometrika 1951, 16, 297-334. [CrossRef] 
71. Gefen, D.; Straub, D.; Boudreau, M.-C. Structural equation modeling and regression: Guidelines for research practice. Commun. Assoc. Inf. Syst. 2000, 4, 7.

72. Bagozzi, R.P.; Yi, Y. On the evaluation of structural equation models. J. Acad. Mark. Sci. 1988, 16, 74-94. [CrossRef]

73. Han, H.; Hsu, L.-T.; Sheu, C. Application of the Theory of Planned Behavior to green hotel choice: Testing the effect of environmental friendly activities. Tour. Manag. 2010, 31, 325-334. [CrossRef]

74. Hofstede, G. Cultural dimensions in management and planning. Asia Pac. J. Manag. 1984, 1, 81-99. [CrossRef]

75. Hofstede, G. Culture's Consequences: Comparing Values, Behaviors, Institutions, and Organizations across Nations; Sage Publications: Thousand Oaks, CA, USA, 2001.

76. Hofstede, G.; Hofstede, G. Cultures and Organizations: Software of the Mind; McGrawHill: New York, NY, USA, 2005.

(c) 2018 by the authors. Licensee MDPI, Basel, Switzerland. This article is an open access article distributed under the terms and conditions of the Creative Commons Attribution (CC BY) license (http://creativecommons.org/licenses/by/4.0/). 